\title{
INFORMATION TECHNOLOGY IMPLEMENTATION ON SOCIALIZATION OF HARMONIOUS CULTURE IN BALI
}

\author{
I Putu Astawa, Ni Putu Wiwiek Ary Susyarini and Ni Nyoman Triyuni. \\ Tourism Business Management, Bali State Polytechnic, Bali, Indonesia \\ E-Mail: putuastawa1@pnb.ac.id
}

\begin{abstract}
The research objective is to build a model of information delivery harmonious culture that is run by Village Credit Institutions (LPD) through information technology to rural communities so that financial performance can be improved. Thirty-five rural credit institutions which meet the criteria were used empirically as a sample. Data such as the practice of cultural values harmony collected through in-depth interviews were then analyzed using descriptive method and ethnomethodology. The model is built starting with the collection of data from each row, perform data classification into three categories of cultural harmony, making a website that contains information on the activities of cultural harmony, then mounting internet in each row to facilitate public access to information on the implementation of cultural harmony. Results of model simulations for three months showed that the level of community participation increased by an average of five percent through credit lending and credit issues decreased by 3.5 percent. Cultural harmony is practiced by $55 \%$ in touch with the God, $35 \%$ related to humans, and 10\% related natural premises. Results of this study implied that IT is no longer expensive but able to create a better performance.
\end{abstract}

Keywords: information technology, harmonious culture, financial performance.

\section{INTRODUCTION}

The success of microfinance institutions is not located in lending but the range of credit services provided to the public (Yaron et al., 1997). Credit services to rural communities is one of the tasks village credit institutions and encourage the creation of an increase in the rural economy, creating jobs, reducing the urbanization of rural areas to cities, and reducing crime. Services such as microfinance institutions are now widely found in Bangladesh, Philippines, Malaysia or in other ASEAN countries. However, the services provided by microfinance institutions in rural areas in Bali are very different because in addition to credit services, it also provides services relating to the maintenance of a culture that developed in each village (Astawa et al., 2013). Maintenance culture is done by microfinance institutions summarized in the concept of harmony culture that emphasizes harmony with God's relationship between the company, employees, communities and the natural environment. Applications of cultural harmony in microfinance institutions have an impact on the efficiency, credit risk and financial performance (Astawa et al., 2012, 2013). Companies that implement a culture of harmony as well have little credit risk (Astawa et al., 2013). The client believes that not paying on time is a denial of the law of karma belief (Astawa, 2013) which means that if done well, it will get the goodness in return. Credit payments on time is part prostrate devotion to the God, because the money in pay will be used by others means helping the embodiment of God.

Application of cultural harmony is one of the tools to encourage people to adhere to an agreement they credit with the aim of not more than five percent (Regional Devt Bank, 2013). These conditions must be addressed by providing an understanding of cultural harmony to all customers or rural communities in order to avoid misunderstandings or different interpretations of harmony cultural practices performed by microfinance institutions. The process of providing an understanding can be done by using information technology.

Today information technology (IT) has been able to assist companies in improving operations and more productive (Brynjolfsson and Hitt, 1996, 2003; Bloom et al., 2012). On the other hand some researchers have found that IT it weakens the natural value of an IT that are innovative (Hobijn and Jovanovic, 2001; Gârleanu et al., 2012a, b; Bartelsman, 2013; Kogan and Papanikolaou, 2013, 2014). Research Chun et al., 2015 confirms that the use of IT to contribute positively to the manufacturing and non-manufacturing. The use of IT in the company has an impact on employment (Sniukienea and Sarkane, 2014), which is associated with increased skills and provide motivation to work better and more productive. Another impact caused by the use of IT is the quality of service and decreasing costs (Bardhan and Thoin, 2013). Quality service through the use of IT fosters consumer confidence, because it is served with fast, accurate, and inexpensive. This concept is no longer dominated by the manufacturing company but in the non-manufacturing companies (Chun et al., 2015) healthcare, hospitality, education, and banking.

IT provides benefits for the company and also social life (Habermas (1984); Zaidi et al. (2015). The use of IT in this study is very different from previous studies where IT is used for socialization program socialization culture of harmony not tangible products such as the company in general. This research builds a model of information delivery harmonious culture run by the Village Credit Institutions (LPD) through information technology to rural communities in order to increase the financial performance can be achieved. Data were collected through in-depth interviews to 35 managers of companies that are selected through purposive sampling with criteria have IT staff and there is telephone access to community (banjar). The data relate to cultural activities that emphasize harmony harmonious relationship with God, man, and nature analyzed by ethnomethodology. Results of analysis of the cultural 
practices of harmony as the content will be disseminated through IT to the public or customers through a model built.

LPD is one of the non-bank microfinance institutions in which the owner is a traditional village institutions or Pakraman (institution) and is the only non-bank microfinance institutions that are managed by custom in Indonesia. The existence of LPD in Bali is set in Bali Provincial Laws No. 2 in 1988, and has been updated with local regulations No. 8 of 2002, with the following characteristics : (1) is a business entity; (2) belonging village (Desa Pakraman); (3) established and managed by Desa Pakraman; (4) organizing functions Desa Pakraman community financial institutions, such as: accept / collect funds from village manners, lend only to the village manners, and manage limited to financial institutions Desa Pakraman environment; and (5) perform the functions of the business as a financial institution's internal efforts Desa Pakraman or as far as inter- Desa Pakraman.

Based on data from the Provincial Government of Bali, LPD's population in the province of Bali in eight districts and one municipality in 2010 is as much as 1,405 units of LPD with employment of 7,396 people and total assets of Rp. 5.18 trillion. LPD condition has exceeded the rural banks (BPR) is there, where the number of assets only totaled 3.142 trillion in the same year, but has a problem of uncollected loans of $9.76 \%$ (Kontan, 2010).

LPD has a unique view on governance by using the traditional rules, including norms, social sanctions, and engagement of leader Pakraman in the selection process and the enforcement of the loan agreement which is not directly made by the Central Bank (BPD). Models such as these tend to exploit the comparative advantage in monitoring and enforcement capacity of sanctions (Stiglitz, 1990). Brinkerhoff (1992) tried to explain the role of institutions in an effort to improve the performance of microfinance institutions (such as: legal, formal regulations, customs, conventions, social norms and codes of conduct) that is held as a driving force of growth companies. Institutional environment is a set of basic rules of social and political fundamental law that became the foundation for the production, trade, and distribution (Davis and North, 1971). Therefore, institutions have an important role because it can create a structure in everyday life by defining and limiting a set of options that are owned by individuals and organizations.

Astawa and Sudika (2014) examined cultures such as praying, honest, hard work, mutual cooperation, and tatwamasi in associate with the financial performance of the company property in Bali. Results of the study showed that culture such as praying, honest, hard work, mutual cooperation, and tatwamasi have a positive effect on improvement of financial performance. Cultural harmony that runs on LPD is the development of an organizational culture Scein (2004) described the study Astawa (2013).
Tabel-1. The Comparison of Schein's Cultural Theory and Harmonious Culture

\begin{tabular}{|l|l|lr|}
\hline Schein & $\begin{array}{l}\text { Harmonious } \\
\text { Culture }\end{array}$ & $\begin{array}{l}\text { Harmonious } \\
\text { Culture }\end{array}$ & Sub- \\
\hline $\begin{array}{l}\text { Basic } \\
\text { assumption }\end{array}$ & Parahyangan & $\begin{array}{l}\text { Sradha dan bhakti, } \\
\text { karmaphala }\end{array}$ \\
\hline $\begin{array}{l}\text { Value } \\
\text { system }\end{array}$ & Pawongan & Tatwam asi, rwa bhineda \\
\hline Artifact & Palemahan & Olas asih \\
\hline
\end{tabular}

Source : Astawa (2013)

Cultural Comparison harmony with the culture Schein (2004) as the harmonization of the relationship with God (parahyangan) which is equal to Basic assumption in practice in LPD reflected on the culture Sradha and bhakti, karmaphala. Where the owners and managers believe through closeness to God means God's attributes will lead in acting like honesty, sincerity, and sincerity. Service is a sacrifice to God and also believed that good deeds will produce good results and vice versa. Through the closeness of God and will no longer lie with the conditions experienced honest. People are afraid to not pay the loan because the services that touch the heart will bring shame to not pay the debt. Harmonization among humans (pawongan) equal to the value system in practice is found respect for the human being with respect for differences. Through respect for human tantamount to honor God because in man there is a soul that is a part of God. Through human treatment equal with God means God's character will be united that will come a sense of mutual respect for each other. There is a harmonization relationship between LPD with the surrounding natural environment (palemahan) together with the artifact. Practice reflected that LPD has a sense of care about the environment. Sense of caring is reflected in the culture olas asih towards the people in the village by taking into account the needs of indigenous and arrangement of the physical environment.

Today the use of IT is important because it has an impact on productivity, creativity, employees, and economic growth (Katz (2009). Lipaj \& Davidaviciene (2013) argues that the information system is constituted by IT can improve the achievement of corporate objectives, targets and strategies owned. The use of IT can add value to the company so it can compete in world global terms. At small companies with good IT governance can compete in global terms and is able to obtain consumer information quickly (Серикова, 2003). Small company that controls IT can play a powerful role as mediating between large companies with consumers. Some researchers link between IT with employee performance such as Oulton (2001), Pilat, Lee and van Ark (2002), Khan and Santos (2002), Van Ark, Inklaar, McGuckin (2003), and Van Ark, Piatkowski (2004). Kogan and Papanikolaou $(2013,2014)$ analyzed the impact on the value of investments in technology companies. The result is that the sensitivity of each company is different to the performance and profit shares this opinion and gain support from Hobijn and 
Jovanovic (2001) and Gârleanu et al. (2012b). Special technology investments including the computers, the steamengine, and the dynamo (David, 1990; Greenwood and Jovanovic, 1999) provides an important role in improving corporate performance

\section{METHODOLOGY}

This research was done in three stages of the first to perform in-depth interviews to thirty-five LPD manager to get data harmonies cultural practices performed. The sampling process used purposive sampling with criteria that have IT staff and there is telephone access to banjar. thirty-five LPD qualified as research sample of 1406 LPD in Bali (Bali Development Bank, 2013). Analysis tools in view of cultural practices that run on LPD through ethnomethodology approach. Ethnomethodology are attempts to describe and understand the people in everyday life, such as how the interaction patterns, ways of thinking, feelings and how to talk (Bungin, 2007). The term ethnomethodology issued by Garfinkel in 1967, refers to the study of the ways in which people make sense of Reviews their social world (Poore, 2000)._Results of this analysis were grouped into three parts, namely cultural activities related to the Lord (parahyangan), cultural activities associated with humans (pawongan), and cultural activities related to nature. The second stage of modeling to convey information by utilizing cultural practices harmony IT owned by LPD and the final step is to carry out the implementation of the model in the village of Kuta Badung. Kuta village is elected as a test of the model because it has telephone access to banjar and LPD has the largest asset in Bali. Test models for three month of May until July 2014) and the results will be analyzed descriptively.

\section{RESULTS AND DISCUSSION}

\section{Practical Harmonious Culture}

The results of in-depth interviews that reflect the harmony of cultural activities related to the God, human beings and the natural environment.

Table- 2. Practical Harmonius Culture

\begin{tabular}{|c|c|}
\hline $\begin{array}{l}\text { Reflexivity study Cultural } \\
\text { Harmony }\end{array}$ & Assessing Indices \\
\hline $\begin{array}{l}\text { 1. The development temple } \\
\text { (Tempat Ibadah) } \\
\text { 2. Temple ceremony (upacara } \\
\text { di Pura) } \\
\text { 3. Donation for ceremony } \\
\text { 4. religious trip }\end{array}$ & Parahyangan (God) \\
\hline $\begin{array}{ll}\text { 5. } & \text { Education and training } \\
\text { 6. } & \text { Health } \\
\text { 7. } & \text { Ngaben and Nyekah } \\
\text { 8. } & \text { Donation for death } \\
\text { 9. } & \text { Arts Group } \\
\text { 10. } & \text { Labor Union }\end{array}$ & Pawongan (Human) \\
\hline $\begin{array}{l}\text { 11. Built building tradisional } \\
\text { market } \\
\text { 12. Development of Village } \\
\text { Hall } \\
\text { 13. Development of Sports } \\
\text { Facilities } \\
\text { 14. Clean beach }\end{array}$ & Palemahan (Environment) \\
\hline
\end{tabular}

\begin{tabular}{|l|l|}
\hline $\begin{array}{l}\text { Reflexivity study Cultural } \\
\text { Harmony }\end{array}$ & Assessing Indices \\
\hline 15. Greening & \\
16. Road repair & \\
17. Repair of drains & \\
18. Making the trash & \\
19. Help plant seeds and fish & \\
20. Parking area & \\
\hline
\end{tabular}

Source: primary data

Rural credit institutions in Bali have run activities associated with God through the creation of a place of worship of God, the teachings through ceremonies and religious activities (Table-2). Belief in God encourages managers to prostrate devotion through ceremonial activities and keep close to God (Astawa, 2013). The closeness to God reflected in the attitude that puts the LPD managers' harmonization in providing credit services. Sincere service without imposed will encourage closeness to customers and the added confidence that if we do good will obtain good results (karmapala) Astawa and Sudika (2014). Through sincere service raises heart closeness between customers with LPD that will encourage honesty to occupy all the agreements made so that the performance can be increased (Yaron et al., 1997; Astawa, et al., 2013).

Human relations problems with LPD managers have helped the villagers to improve education and health through several programs such as scholarships, medical benefits. Other aid in the form of funds deaths and conduct a joint ceremony on a tribute to the ancestors (cremation and nyekah). This activity provides a touch hearts for villagers who feel respected human ancestors even well respected by LPD. Touch services out of the modern management rules that are rigid create LPD closeness with the community difficult to separate. It can be seen LPD has an important role in driving the economy of the village in Bali (Nurcahya, 2006). Pawongan dimension is the harmonious relationship between human beings (Surpha, 2001; Wiana, 2004; Ashrama, 2005), in the context of the business necessary to build a harmonious relationship of internal employees, between employees and management of the company and between the company's management with communities (Ashrama, 2005). In details Ashrama (2005) says that the harmonious relationship can be indicated on several things, such as: the existence of groups in organizations such as trade unions, sekehasekeha and companies maintain a harmonious relationship with the community through poverty alleviation programs, utilizing local labor and skills training.

Palemahan, the last dimension, is associated with the physical aspects of the environment around us or the company (Surpha, 2001; Wiana, 2004; Ashrama, 2005). Ashrama (2005) explains that the layout of the company and the existing building should be adapted to religious beliefs and cultures that exist. LPD managers have supported previous research that physical aspect has been considered properly through the construction of facilities and infrastructure (Table 2) as well as providing assistance plant seeds and fingerlings. Keeping the environment in which the company was founded in harmonious order LPD managers have 
understood well. The concept of harmonious relationship with environments provides benefit to the value of the company and supports the government's green program. This concept is already a famous Balinese culture with compassion Olas (Astawa and Sudika, 2014) meaning that damage the environment means damage to the company, thus safeguarding the environment is a must.

\section{Submission of Harmony Culture Model-Based IT}

Researchers had previously explained that IT has a role in improving the performance or productivity of employees. In this study makes the model to convey the harmony of cultural reflexivity of the activities carried out by the LPD. Qualitative analysis results obtained twenty reflexivity of harmony culture (Table- .2) which were divided into three indices namely parahyangan, pawongan, and palemahan. The third dimension of cultural harmony created a model in the form of a website.

The function of the website is to convey information on the plans and activities of cultural harmony to the villagers. To maintain information on each row is given the right to inform the harmony of cultural activities that have been planned or are already underway. Submission of this information is done by the head of the banjo by using the ID and password provided by admin at LPD. Each community can access and view the information culture of harmony in the website by using the ID and password provided by admin. All information is stored in a database and in each row is provided along with wifi computer that is used as a tool by the head row to enter the data from the public. This model can be described in Figure-1.

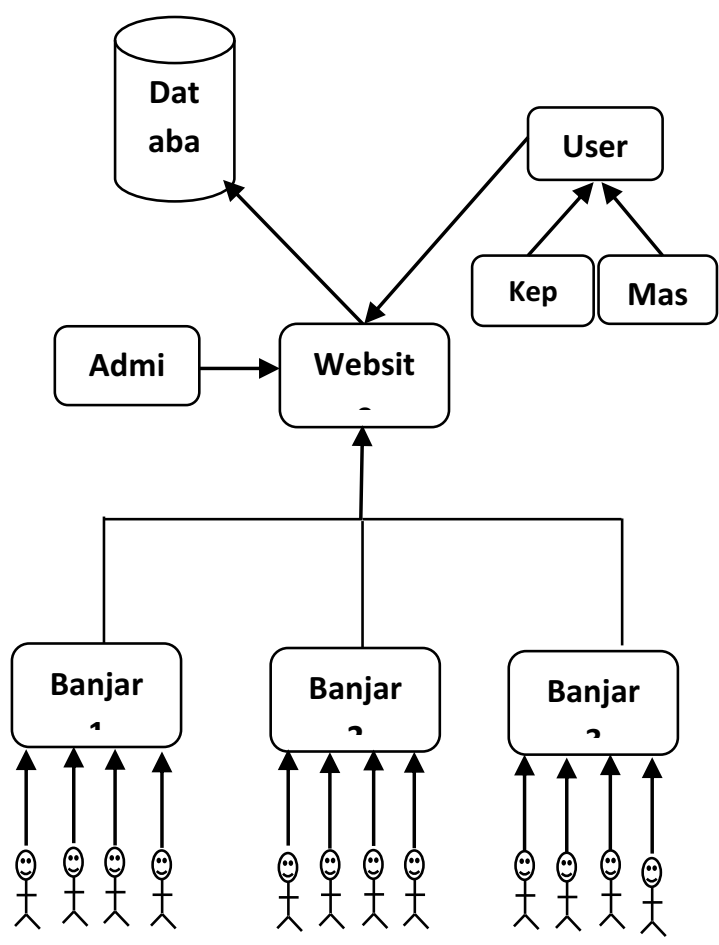

Figure-1. Harmony Model of Cultural Information Technology Systems

\section{IMPLEMENTATION MODEL RESULT}

Once the model is created, it was followed by implementation for three months (March - May 2014) and the results are described in Table- 3 .

Table- 3. Result 1 Implementation Model

\begin{tabular}{|c|c|c|}
\hline $\begin{array}{l}\text { Reflexivity } \\
\text { study } \\
\text { Cultural } \\
\text { Harmony } \\
\end{array}$ & Assessing Indeksikalitas & $\begin{array}{l}\text { No. } \\
\text { Activities }\end{array}$ \\
\hline Parahyangan & $\begin{array}{l}\text { The development temple (Tempat } \\
\text { Ibadah) } \\
\text { Temple ceremony (upacara di Pura) } \\
\text { Donation for ceremony } \\
\text { religious trip }\end{array}$ & $\begin{array}{l}0 \\
4 \\
6 \\
1\end{array}$ \\
\hline Pawongan & $\begin{array}{l}\text { Education and training } \\
\text { Health } \\
\text { Ngaben dan Nyekah } \\
\text { Donation for death } \\
\text { Arts Group } \\
\text { Labor Union }\end{array}$ & $\begin{array}{l}1 \\
2 \\
0 \\
3 \\
1 \\
0\end{array}$ \\
\hline Palemahan & $\begin{array}{l}\text { Built building traditional market } \\
\text { Development Balai Desa } \\
\text { Development of Sports Facilities } \\
\text { Clean beach } \\
\text { Greening } \\
\text { Road repair } \\
\text { Repair of drains } \\
\text { Making the trash } \\
\text { Help plant seeds and fish } \\
\text { Parking area }\end{array}$ & $\begin{array}{l}0 \\
0 \\
0 \\
0 \\
0 \\
1 \\
0 \\
1 \\
0 \\
0\end{array}$ \\
\hline
\end{tabular}

Source: Study result model (2014)

The test results obtained by the model during the three months of activity related to the donation for the biggest ceremony then continued with piodalan in the temple and death donation number three. The third major activity lies in parahyangan and pawongan. Another said that the twenty existing activities $55 \%$ is related to the activity of God (parahyangan), $35 \%$ relate to human beings (pawongan), and $10 \%$ related to the environment (palemahan). These results have been demonstrated in previous studies Astawa et al., (2013) the cultural practice of harmony which contains the trust God has been run regularly through religious activities. Balinese people are confident and believe that prosperity is achieved when realized harmonious relationship between man and God creator (Surpha, 2001; Wiana, 2004; Ashrama, 2005). Business activity is an offering which therefore does not escape from the control of the Lord (Widia and Goddess, 2007). So the company is expected to seek as much as possible the emergence of shades relegius (divinity) both inside and outside the corporate environment (Ashrama, 2005, Widia and Dewi, 2007). The observation of model testing also found that the number of clients served in April 2014 amounted to 734 people; the month of May 2014 totaled 801, in June 2014 amounted to 841, and in July 2014 
amounted to 883 . The increase in loan servicing of observation has increased an average of $5 \%$ per month. Number of bad credit problems in the early months of May 2014 amounted to Rp 167 million and at the end of the month of July 2015 amounted to 161 million decreased by $3.5 \%$. Program clarity and evidence submitted through the website activities provide benefits to society. IT has an important role in accelerating the delivery of information, so the impact will be more credit services. This condition will drive corporate performance increase (Lipaj \& Davidaviciene, 2013). One measure of the performance of financial institutions is credit problems. The trial period decreased credit crunch models suggesting IT has a role in the achievement of corporate performance (David, 1990; Greenwood and Jovanovic, 1999; Katz, 2009, Liu S. and Wang L., 2014). The results also support the research Chun et al., 2015 confirms that the use of IT to contribute positively to the manufacturing and nonmanufacturing companies. The result also support the research ( Foster et al. 2001; 2006; Acemoglu et al.; 2012; Kogan et al.; 2012, 2013; 2014; Marinagi et al., 2014) use IT can improve productivity.

\section{CONCLUSION}

Cultural socialization of harmony using IT accelerates the communication between the customer and LPD, causing a sense of belonging to the LPD higher because the service is based on a harmonious relationship. Harmonious relations based on the culture of keeping harmony between LPD harmony with the community, environment and God as creator of all that exists on earth.

\section{REFERENCES}

Ashrama, Berata, 2005. "The Essence of THK and Its Referential Teaching " Tri Hita Karana -Tourism Awards and Accreditations.

Astawa P. I, Sudarma M., Aisjah S., Djumahir, 2012. Credit Risk and Harmonious Values Practice (Study at Village Credit Institution (Lembaga Perkreditan Desa) Of Bali Province), Journal of Business and Management, Volume 6, Issue 4, PP 16-20

Astawa P. I., 2013. Ownership in the Perspective of Ethnomethodology at the Village Credit Institutional in Bali, Research Journal of Finance and Accounting, Vol. 4, No.8, pp 55-62

Astawa P. I., Sudarma M., Aisjah S., Djumahir, 2013. Institutional Ownership and Harmonious Values in Increasing Financial Performance of Village Credit Institution (Lembaga Perkreditan Rakyat/ LPD) in Bali
Province, Journal of Basic and Applied Scientific Research, Vol. 3, No. 6, pp 813-824.

Astawa P. I. and Sudika P., 2014. The Impact Local Culture On Financial Performance In Property Firms In Bali, Asia Pacific Management and Business Application, Vol 3, No. 2, pp 106-115

Bank Pembangunan Daerah (BPD). 2013. Laporan Tahunan Lembaga Perkreditan Desa Provinsi Bali.

Bardhan Indranil R and Thouin Mark F. 2013. Health information technology and its impact on the quality and cost of healthcare delivery. Decision Support Systems 55, pp 438-449

Bartelsman, E.J., 2013. ICT, reallocation and productivity. In: European Economy-Economic Papers No. 486.

Bloom, N., Sadun, R., Van Reenen, J., 2012. Americans do I.T. better: US multinationals and the productivity miracle. American Economic Review No. 102, pp 167201.

Brinkerhoff, 1992. Promoting the Sustainability of Development Institutions : A Framework for Strategy. World Development, Vol. 20 (3), pp 369-383.

Brynjolfsson, E., Hitt, L., 1996. Paradox lost? Firm-level evidence on the returns to information systems spending. Management Science Vol. 42, pp 541-558.

Brynjolfsson, E., Hitt, L., 2003. Computing productivity: firm-level evidence. Reviewof Economics and Statistics Vo. 85, pp 793-808.

Bungin, Burhan. 2007. Metodologi Penelitian Kualitatif: Aktualisasi Metodologis ke arah Ragam Varian Kontemporer. Penerbit. Jakarta.

Chun H., Kim J.W., Lee J., 2015. How does information technology improve aggregate productivity? A new channel of productivity dispersion and reallocation. Research Policy Vol. 44, pp 999-1016

Серикова, Н. К. 2003. Оценка влияния ИКТ на экономический рост. Available from internet: http://wiasite.com/elektronnoy-

kommertsiiosnovy/otsenka-vliyaniya-iktekonomicheskiy.htm1

David, P.A., 1990. The dynamo and the computer: a historical perspec-tive on the modern productivity paradox. American Economic Review Vol. 80, pp 355361 .

Davis, Lance E. \& Douglas C. North, 1971. Institutional Change and American Economic Growth. Cambridge: Cambridge University Press. 
Foster, L., Haltiwanger, J., Krizan, C.J., 2001. Aggregate productivity growth: lessons from microeconomic evidence. In: Hulten, C.R., Dean, E.R., Harper, M.J. (Eds.),New Developments in Productivity Analysis. University of Chicago Press, Chicago, pp. 303-372.

Foster, L., Haltiwanger, J., Krizan, C.J., 2006. Market selection, reallocation, and restructuring in the U.S. retail trade sector in the 1990. Review of Economics and Statistics Vol. 88, pp 748-758.

Gârleanu, N., Kogan, L., Panageas, S., 2012a. Displacement risk and asset returns.Journal of Financial Economics Vol. 105, pp 491-510.

Gârleanu, N., Panageas, S., Yu, J., 2012b. Technological growth and asset pricing. Journal of Finance Vol. 67, pp 1265-1292.

Greenwood, J., Jovanovic, B., 1999. The informationtechnology revolution and thestock market. American Economic Review Vol. 89, pp 116-122.

Habermas J. 1984. The theory of communicative action (T.McCarthy, Trans.). Boston: Beacon Press; 1984 (Original work published 1981).

Hobijn, B., Jovanovic, B., 2001. The information technology revolution and the stock market: evidence. American Economic Review 91, 1203-1220

Katz, R.L. 2009. The Economic and Social Impact of Telecommunications Output. Intereconomics, pp 41-48. http://dx.doi.org/10.1007/s10272-009-0276-0.

Khan, H. \& Santos, M. 2002. Contribution of ICT Use to Output and Labour Productivity Growth in Canada. Bank of Canada Working Paper

Kogan, L., Papanikolaou, D., 2013. Firm characteristics and stock returns: the role of investment-specific shocks. Review of Financial Studies Vol. 26, pp 2718-2759.

Kogan, L., Papanikolaou, D., 2013. Firm characteristics and stock returns: the role of investment-specific shocks. Review of Financial Studies Vol. 26, pp 27182759 .

Kogan, L., Papanikolaou, D., Seru, A., Stoffman, N., 2012. Technological innovation, resource allocation, and growth.In:NBER Working Paper No.17769.

Kogan, L., Papanikolaou, D., 2014. Growth opportunities, technology shocks, and asset prices. Journal of Finance Vol. 69, pp 675-718.

Kogan, L., Papanikolaou, D., Seru, A., Stoffman, N., 2012. Technological innovation, resource allocation, and growth. In: NBER Working Paper No. 17769.

Kontan, 2010. Lembaga Kredit Desa Beraset Raksasa, Kontan 29 Desember 2010 Halaman 11
Lipaj, D. \& Davidavičienè, V. 2013. Influence of Information System of Business Performance. Science Future of Lithuania. Vol. 5(1), pp 38-45, http://dx.doi.org/10.3846/mla.2013.06

Liu S. and Wang L., 2014. Understanding the impact of risks on performance in internal and outsourced information technology projects: The role of strategic importance. International Journal of Project Management Vol. 32 pp 1494-1510

Marinagi C., Trivellas P.,Sakas D.P., 2014. The impact of Information Technology on the development of Supply Chain Competitive Advantage. Procedia Social and Behavioral Sciences Vol. 147 pp 586-591

Nurcahya Ketut I. 2006. LPD di Bali Suatu Contoh dari Lembaga Keuangan Mikro Yang Bertahan.Buletin Studi Ekonomi . Vol. 11. No. 3. Pp 210-217

Oulton, N. (2001). ICT and Productivity Growth in the UK. Bank of England: London.

Pilat, D., Lee, F. \& van Ark, B. (2002). Production and Use of ICT: a Sectoral perspective on Productivity Growth in OECD Area. OECD Economic Studies. No 35 , pp 48-76.

Poore, Simon. 2000. An ethnomethodology- An introduction. www.hewett.norfolk.sch.uk. Diunduh 3 April 2008.

Schein, Edgar, H. 2004. Organizational Culture and Leadership,John Wiley and Sont.Inc

Šniukienėa Alma Mačiulytė and Sarkane Elina Gaile. 2014. Impact of information and telecommunication technologies development on labour productivity. Procedia - Social and Behavioral Sciences Vol. 110, pp $1271-1282$.

Stiglitz, Joseph E. 1990. Peer Monitoring and Credit Markets. The World Bank Economic Review, Vol. 4(3), pp 351-66

Surpha Wayan Gede. 2001. Budaya Organisasi, Teori Praktis, Kasus, dan Aplikasi Penelitian. Penerbit Udayana University Press, Denpasar

Van Ark, B., Inklaar, R. \& McGuckin, R.H. 2003. ICT and Productivity in Europe and the United States. Where Do the Differences Come From? CESifo Economic Studies, Vol. 49(3), pp 295318http://dx.doi.org/10.1093/cesifo/49.3.295

Van Ark, B. \& Piatkowski, M. 2004. Productivity, Innovation and ICT in Old and New Europe. University of Groningen. Research Memorandum.

Wiana, I Ketut, 2004. Mengapa Bali disebut Bali. Penerbit Paramita Surabaya. 
Wiana, I Ketut, 2007. Tri Hita Karana Menurut Konsep Hindu. Penerbit Paramita Surabaya

Windia, W., dan Ratna K. Dewi. 2007. Analisis Bisnis yang Berlandaskan Tri Hita Karana, Penerbit Universitas, Udayana, Denpasar.

Yaron, Yacob, McDonald Benjamin \& Gerda Piprek.1977 Rural Finance: Issue, Design, and the Best Practice, Environmentally and Socially Sustainable Development Studies and Monographs Series 14. Washington D.C.: The World Bank.

Zaidi A U., Shanti F., Nawal A., 2015 . An exploratory study of the impact of information communication technology (ICT) or computer mediated communication (CMC) on the level of violence and access to service among intimate partner violence (IPV) survivors in Canada. Technology in Society Vol. 41, pp 91-97 